\title{
PŘíPRAVA AKREDITOVANÝCH VZDĚLÁVACÍCH KURZŮ CAGI A KMEN ZNALOSTÍ
}

\author{
Jiří HORÁK ${ }^{1}$
}

${ }^{1}$ Katedra geoinformatiky, Hornicko-geologická fakulta, Vysoká škola báňská - Technická univerzita Ostrava, 17. listopadu 15, 70833 Ostrava, Česká republika

jiri.horak@vsb.cz

doi: https://doi.org/10.31490/9788024843988-9

\begin{abstract}
Abstrakt
V roce 2019 byla CAGI reakreditována jako vzdělávací instituce pro průběžné vzdělávání pro úředníky a pro vedoucí úředníky úředníků v samosprávě. Rovněž se podařilo úspěšně dokončit akreditaci 3 kurzů (vzdělávacích programů). „Geografické informační systémy pro e-government l“ je úvodním kurzem do problematiky GIS, určený pro nejširší skupinu začínajících pracovníků GIS, v kombinované formě s 6 dvoudenními soustředěními. Stejný formát má i druhý kurz, „Geografické informační systémy v územním plánování“, který je určen pro úředníky VS zaměřené na problematiku pořizování ÚAP. „Bezpilotní letecké prostředky (UAV) v ochraně životního prostředí“ je krátký dvoudenní kurz. $V$ prípravě akreditace jsou ještě další kurzy. Příspěvek seznámí s podrobnějším plánem realizace kurzů a shrne další aktivity $v$ oblasti vzdělávání. Jednou z nich je i nová verze GI Body of Knowledge.
\end{abstract}

\section{Abstract}

Certified Educational Courses of Czech Association for Geoinformation and Body of Knowledge: In 2019 the Czech Association for Geoinformation was certified as an educational institution for lifelong learning dedicated clerks and chief clerks in self-administration bodies. Three courses were successfully certified. "Geographical information systems for e-Governement l" is an introductory course into the GIS field suitable for a wider group of beginners. A combined form of study includes 6 workshops lasting two days. The same format was applied also for the second course, a Geographical Information Systems in urban planning" intended for clerks focused on acquisition of urban-analytical data. A "UAV in environmental protection" is the name of a short term course. Several other courses are under preparation. The paper introduces also more detail planes of conducting these courses and summarizes other educational activities. One of them is a new version of GI Body of Knowledge.

Klíčová slova: vzdělávání; celoživotní vzdělávání; GIS; kmen znalostí

Keywords: education; lifelong learning; GIS; Body of Knowledge

1. ÚVOD

Rozvoj národní geoinformační infrastruktury není možný bez zajištění dostatečného rozvoje lidských zdrojů, na jejichž prípravě se podílí zejména vzdělávání v různých formách.

Česká asociace pro geoinformace podporuje rozvoj vzdělávání zejména v oblasti dalšího vzdělávání. Konkrétním výsledkem jejích aktivit byla akreditace několika vzdělávacích kurzů podle zákona č. 312/2002 Sb., o úřednících územních samosprávných celků, aby bylo možné toto vzdělání úředníkům uznávat $v$ rámci jejich celoživotního vzdělávání.

Současně je také potřebné sledovat rozvoj požadavků na pracovní pozice a vymezování skupin dovedností a znalostí požadovaných v oblasti GI Science and Technology. To se odráží v rozvoji kmenů znalostí, které jsou postupně v naší doméně i v přibuzných oborech připravovány.

Cílem př́spěvku je informovat o aktuálním stavu přípravy kurzů a rovněž upozornit na současný vývoj v oblasti kmenů znalostí, zejména v zahraničí. 


\section{AKREDITOVANÉ VZDĚLÁVACÍ KURZY CAGI}

$\checkmark$ roce 2019 byla CAGI úspěšně akreditována jako vzdělávací instituce MV podle zákona č. 312/2002 Sb. o úřednících územních samosprávných celků a podařilo se akreditovat 3 vzdělávací programy:

- Geografické informační systémy pro e-government I

- Geografické informační systémy v územním plánování

- Bezpilotní letecké prostředky (UAV) v ochraně životního prostředí

Stále v př́pravě pro akreditaci jsou ještě další 2 programy:

- Digitální technická mapa ČR a proces stavebního řízení (připravuje doc. V. Čada)

- Využití dat z družic Sentinel (připravuje doc. V. Pechanec)

Je možné připravit $\mathrm{k}$ akreditaci i další kurzy podle zájmu. Vítáme $\mathrm{v}$ tomto směru iniciativu dalších subjektů a podpoříme je $v$ tom. Je výhodné chystat akreditaci společně, protože to umožňuje využít jednotnou př́ípravu, pouze jednou příprava životopisu a souhlas zapojení, jednotnou přípravu oponentských posudků, zajištění literatury, e-learningu a další náležitosti.

Na kurzech učí pouze lektoři schválení akreditačním orgánem (MV).

Z hlediska zaměření i profilu kurzů je doporučeno vybírat témata ve vazbě na Národní kmen znalostí GIS\&T (Horák et al., 2017a), který je k dispozici ve formě XLSX na adrese http://www.cagi.cz/narodni-kmenznalosti-gist a metodiky na adrese http://www.cagi.cz/navrh-doporucujicich-narodnich-kurikul-v-oblasti-prostinformaci.

Základní informace o jednotlivých kurzech následuje.

\subsection{GEOGRAFICKÉ INFORMAČNÍ SYSTÉMY PRO E-GOVERNMENT I}

Program koordinuje doc. Dr. Ing. Jiří Horák (VŠB-TU Ostrava) a využívá široké konsorcium lektorů (VŠB-TU Ostrava, UP Olomouc, ZČU PIzeň, UK Praha). Je koncipován jako úvodní kurz do problematiky GIS a je určen pro nejširší skupinu úředníků a vedoucích úředníků VS. Jde o kombinovanou formu studia, celkově 3 měsíce, zahrnující 5 soustředění ve čtvrtek-pátek a závěrečné jednodenní soustředění, doplněnou 40 hodinami e-learningu.

Jednotlivá soustředění jsou zaměřena na:

- Základy GIS

- Zdroje geodat a základní manipulace s geodaty

- Analýzy, modelování a výstupy

- Dálkový průzkum Země

- Internetové technologie a legislativa

- Závěrečný seminář

První běh kurzu je naplánován na září až listopad 2020 a bude se konat v Praze na Novotného lávce, pokud současná epidemie odezní včas. Vzhledem k nemožnosti zajistit počítačové učebny pro celé období bude potřebné si donést vlastní notebooky. Pro celé období kurzu dostanou účastníci vlastní licenci ArcGIS. Plánovaná cena kurzu je 17900 Kč.

\subsection{GEOGRAFICKÉ INFORMAČNÍ SYSTÉMY V ÚZEMNÍM PLÁNOVÁNÍ}

Iniciátorem kurzu je doc. RNDr. Jaroslav Burian, Ph.D. (UP Olomouc). Jde o kurz pro pokročilé, který předpokládá základní znalost GIS či alespoň CAD. Je určen pro úředníky VS zaměřené na problematiku pořizování ÚAP. Formát kurzu je 6 soustředění po 2 dnech a e-learning.

Jednotlivá soustředění jsou zaměřena na:

- Moderní datové zdroje - možnosti jejich sběru, využití a zpřístupnění

- Automatizace zpracování geodat

- Prostorové analýzy, modelování, predikce a simulace

- Geovizualizace

- Webové mapové aplikace a mobilní aplikace

- Využití metod DPZ

První běh kurzu by mohl začít v září 2020 .

Cena kurzu je 16900 Kč. 


\subsection{BEZPILOTNÍ LETECKÉ PROSTŘEDKY (UAV) V OCHRANĚ ŽIVOTNÍHO PROSTŘEDÍ}

Garantem kurzu je Doc. Ing. Michal Kačmařík, Ph.D. (VŠB-TU Ostrava). Je určen pro úředníky odborů ochrany př́rody úřadů samosprávy. Bude mít prezenční formu na 2 dny (20 hodin).

Obsah:

- UAV - úvod do problematiky, legislativní rámec

- UAV - dostupné vybavení, pořizování snímků

- Létaní a snímkování s UAV (koptéra, pevné křídlo)

- Zpracování a vyhodnocení dat ze sensorů UAV

- Zpracování a vyhodnocení RGB snímků

- Zpracování a vyhodnocení multispektrálních a termálních snímků

Možná realizace je na podzim 2020. Cena není zatím stanovena.

\subsection{OSTATNÍ ČINNOST}

Činnost OS Vzdělávání se nezaměřuje pouze na prípravu kurzů, ale i na podporu dalších forem vzdělávání, v současnosti stále významnější distanční podobě vzdělávání.

V roce 2019 jsme také navrhli zavedení čtyř nově vymezených povolání do Národní soustavy povolání (Samostatný geoinformatik, Geoinformatik specialista, Geomatik technik, Geomatik specialista) (Horák, 2019b) a provedli dodatečnou analýzu dat $z$ dotazníkového šetření provedeného $v$ rámci TAČR Beta TB9500MV004 „Metodika vyhodnocování lidských zdrojů v oblasti prostorových informaci“" (Čada et al., 2016, Horák, 2019a, Horák, 2019b).

Samostatnou kapitolou je také sledování vývoje studijních programů na vysokých školách (včetně počtu absolventů) a rovněž sledování vývoje $v$ oblasti kmenů znalostí, které ukazují vývoj ve směřování profilování vzdělávání, zejména ve vazbě na vývoj profesí, požadovaných schopností a dovedností.

\section{KMENY ZNALOSTÍ V GEOINFORMATICE}

Kmenem znalostí rozumíme sadu konceptů, které budují profesní doménu. Jedna z řady definic uvádí, že jde o množinu znalostí v profesní nebo předmětné oblasti, které jsou považovány za podstatné a obecně známé (Oliver, 2012).

Významným krokem (i když ne prvním) v naší doméně byla příprava UCGIS BoK pro oblast GI Science \& Technology, která reagovala na objevující se stižnosti na nedostatek specialistů pro GIS\&T vycházejících ze škol a současně stížnosti na nedostatečné (technické) dovednosti těchto absolventů. Podle DiBiase et al. (2006) spočivá využití GIS\&T Body of Knowledge především v plánování studijních programů a jejich revize, akreditace programů, hodnocení programů, vzájemné uznávání výsledků studia a přenositelnost, profesionální certifikace a sledování zaměstnanců.

Systém byl postaven jako hierarchický, s 10 oblastmi znalostí, které se členily na jednotky a ty na témata (celkem 352 témat), u kterých byly dokonce stanoveny výukové cíle. Vzhledem k rozsahu znalostí se ani nepředpokládalo, že by některý studijní program či kurz pokrýval všechna témata. Představovalo to však významný krok ve standardizaci obsahu studia a umožnil i vzájemné porovnávání.

UCGIS BoK je součástí širšího Geospatial Technology Competency Modelu (GTCM, 2014), který obsahuje i osobnostní akademické, pracovní a sektorové dovednosti.

Předpokládalo se, že po 10 letech bude provedena aktualizace tohoto BoK, tj. obsah bude zafixován po 10 let. To navazovalo na podobné BoK vznikající v té době - pro srovnávní např. BoK pro softwarové inženýrství měl mít aktualizační periodu 8 let. K aktualizaci BoK Gl Science \& Technology však nedošlo, resp. došlo ke změně př́stupu a filosofie.

V roce 2016 řešila VŠB-TU Ostrava společně se ZČU projekt TAČR-beta TB9500MV005 „Návrh doporučujících národních kurikul v oblasti prostorových informaci“", který zajistil překlad UCGIS BoK, ale také její rozšíření o další oblasti (zejména web based $\mathrm{Gl}$ ), doplnění národní specifik, doplnění potřeb z praxe, mimo jiné s využitím analýzy strategických dokumentů a analýzy trendů (Jedlička et al., 2017). Projekt poukázal na skutečnost, že nelze při prípravě programů vycházet pouze z BoK pro Gl Science \& Technology, ale že je potřebné sledovat i navazující kompetence, zejména z oblasti geografie, databázových systémů a obecněji informačních technologií. 
Jako hlavní výstup k projektu vznikla metodika „Návrh doporučujících národních kurikul v oblasti prostorových informací a systému komplexních vzdělávacích aktivit pro oblast $\mathrm{Pl}$ “, která je k dispozici na http://www.cagi.cz/navrh-doporucujicich-narodnich-kurikul-v-oblasti-prost-informaci. Jejím cílem bylo:

1. Vytvořit Kmen znalostí GIS\&T jako základní referenční materiál se seznamem doporučených odborných a jiných kompetencí pro oblast prostorových informací.

2. Používat Kmen znalostí GIS\&T pro posuzování odborného zaměření vzdělávacích programů, ovlivňování vývoje obsahu výuky, srovnávání programů a také výběr vhodných kandidátů (absolventů vysokoškolského studia) na danou pozici vzhledem $\mathrm{k}$ jejich specifickému profilu, a pro systematické další vzdělávání zaměstnanců.

3. Doporučit, co by měla národní vysokoškolská kurikula v oblasti prostorových informací obsahovat.

4. Vybudovat systém komplexních vzdělávacích aktivit pro oblast prostorových informací, príipravit a realizovat různé formy vzdělávacích aktivit pro oblast prostorových informací.

Současně byla provedena analýza českých a vybraných zahraničních vysokoškolských GI programů s cílem vyhodnotit zaměření jednotlivých studijních programů a identifikovat málo pokryté oblasti, na jejichž rozvoj je třeba pamatovat při prípravě nových akreditací nebo při př́ípravě kurzů dalšího vzdělávání (Horák et al., 2017b).

Požadavky na studijní profily byly vztaženy vůči 3 hlavním předpokládaným směrům pracovních rolí: Positioning and Data Acquisition, Analysis and Modeling, Software and Application Development.

Mezi hlavní chybějící témata u většiny programů byly zařazeny témata Geocomputation, Organizační a institucionální aspekty, GIS\&T a společnost či návrhové aspekty. Vyplývá to i ze souhrnného hodnocení podílu předmětů $s$ nulovým zastoupením témat (obr.1), kde tmavě hnědá označuje témata a oblasti s nízkým pokrytím v obsahu vysokoškolských programů v tehdejší době.

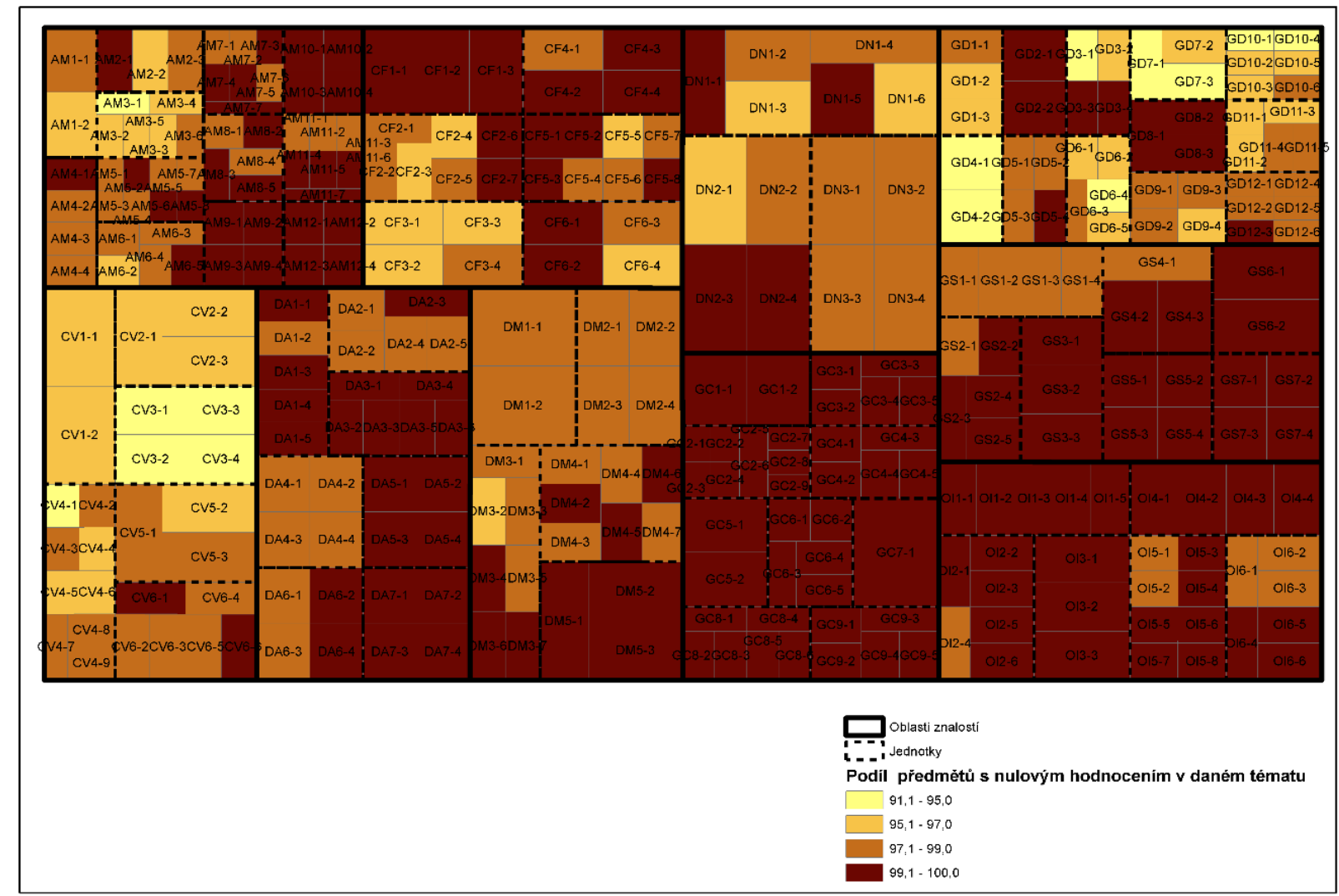

Obr. 1 Podíl zastoupení předmětů s nulovým hodnocením shody v daném tématu (\%) BoK (Horák et al, 2016)

Analýza obsahu studia byla zaslána garantům oborů, u většiny z nich jsme se však nesetkali se zájmem problematiku diskutovat a dále se společným budování znalostní domény zabývat. Bohužel platí, že si každý tvoří obsah svého studijního programu zcela nezávisle a profily studentů nejsou porovnatelné. 
Ve stejném období probíhal mezinárodní projekt GI-N2K (Geographic Information: Need to Know), který na UCGIS BoK navazoval, také prováděl aktualizaci a doplnění témat (celkově 436 témat), avšak zabýval se hlavně nově ontologickým přístupem (BoK VIZ) a budování Wiki pro zajištění průběžné aktualizace témat. Díky novým přístupům již bylo možné vuyžít sítové a nejen hierarchické vazby v systému témat a konceptů, což umožňuje přesnější a flexibilnější vyjádření reálných vztahů.

Současně je potřeba poukázat i na vývoj kmenů znalostí v př́buzných oborech, které jsou pro nás využitelné nebo bychom se s nimi měli seznámit. Jde zejména o softwarové inženýrství, měřictví a v posledním období se mluvilo rovněž o prípravě BoK pro kartografii.

Na projekt GI-N2K určitým způsobem navazuje i aktuální projekt EO4GEO.

EO4GEO je projektem Erasmus+ Sector Skills Alliance a zahrnuje 26 partnerů z 13 zemí (http://www.eo4geo.eu/about-eo4geo/). Jejím cílem je príipravit novou verzi BoK pro oblast GI (BoK EO/GI), se zvláštním zřetelem na DPZ, a přispět $k$ transformaci dalšího vzdělávání, ale i vysokoškolských programů (a prípravě panevropského studia).

K přípravě používá řadu nástrojů, včetně analýz požadavků, analýzy trendů, analýzy webových zdrojů, dotazníkového šetření, polostrukturovaných rozhovorů, byznys modelování nad prípadovými studiemi.

$\checkmark$ roce 2018 bylo provedeno dotazníkové šetření, kterého se účastnilo 128 organizací, s cílem identifikovat vhodné zdroje pro vzdělávání.

V rámci rozhovorů se zástupci různých organizací zjištovali požadované oblasti znalostí ve vztahu k pracovním pozicím (obr. 2).

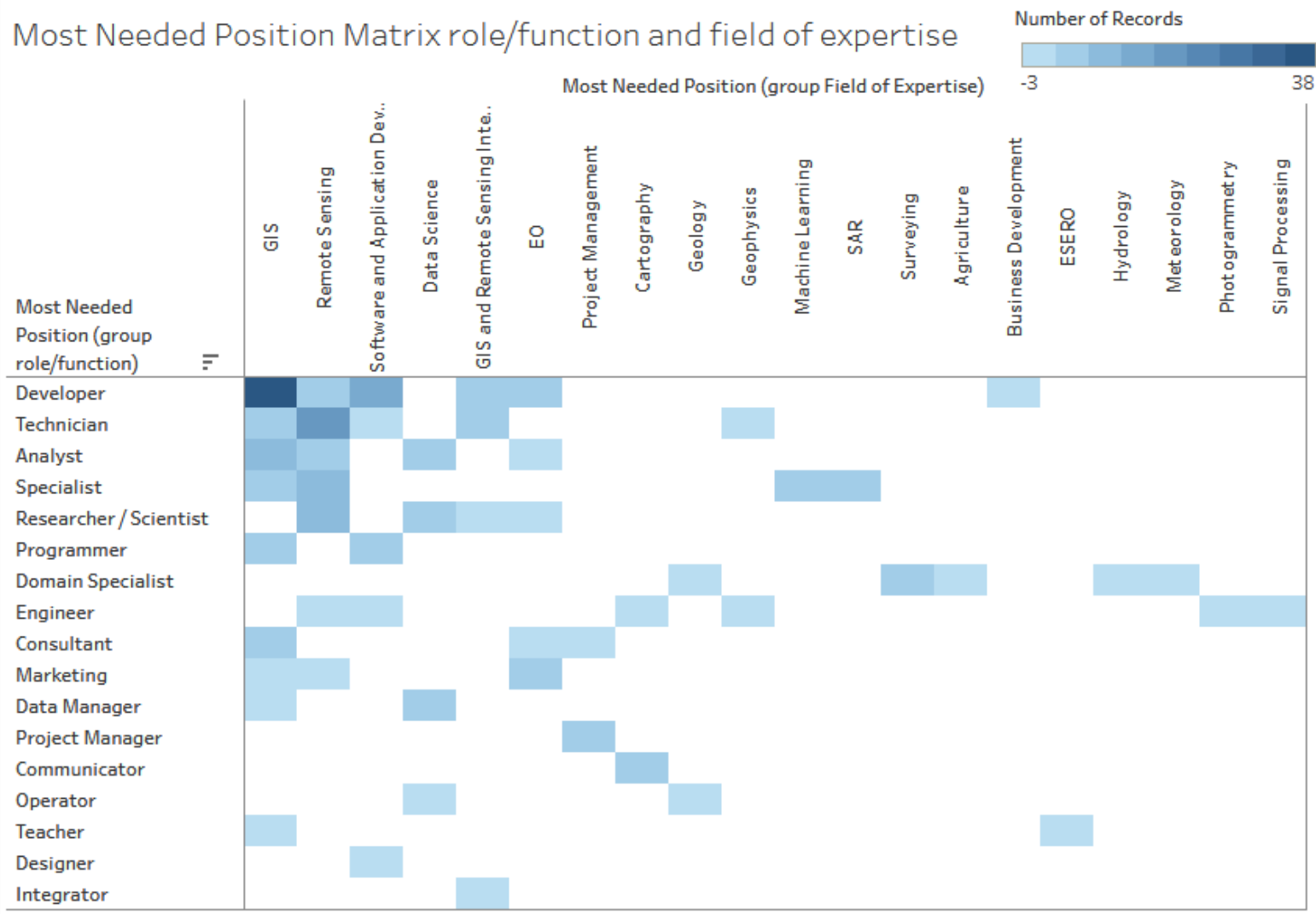

Obr. 2 Požadované oblasti znalostí pro jednotlivé role z rozhovorů (Albrecht, 2018)

Detailně se zaměřili na vybrané skupiny dovednosti, jejichž potřebnost měli respondenti pro jednotlivé pracovní pozice vyhodnotit (Hofer et al., 2019):

- Práce s prostorovými daty (Space/Geospatial Data skills)

- Vizualizace a kartografie (Visualization and Cartography)

- Analytické metody (Analytical Methods)

- Programování a vývoj (Programming and Development)

- Sběr dat a jejich rízení (Data Capture and Management)

- DPZ/GI a společnost (EO/GI and Society)

- Výpočetní zdroje a platformy (Computing Resources and Platforms) 
- Organizační a institucionální aspekty (Organizational and Institutional aspects)

Následně byla vyhodnocena úroveň potřebných znalostí pro každou dovednost, přiděleny váhy a vypočten průměrný rating pro každou skupinu dovedností, aby bylo možné porovnat náročnost jednotlivých činností (obr.3).

\section{Space/Geospatial Data}

90
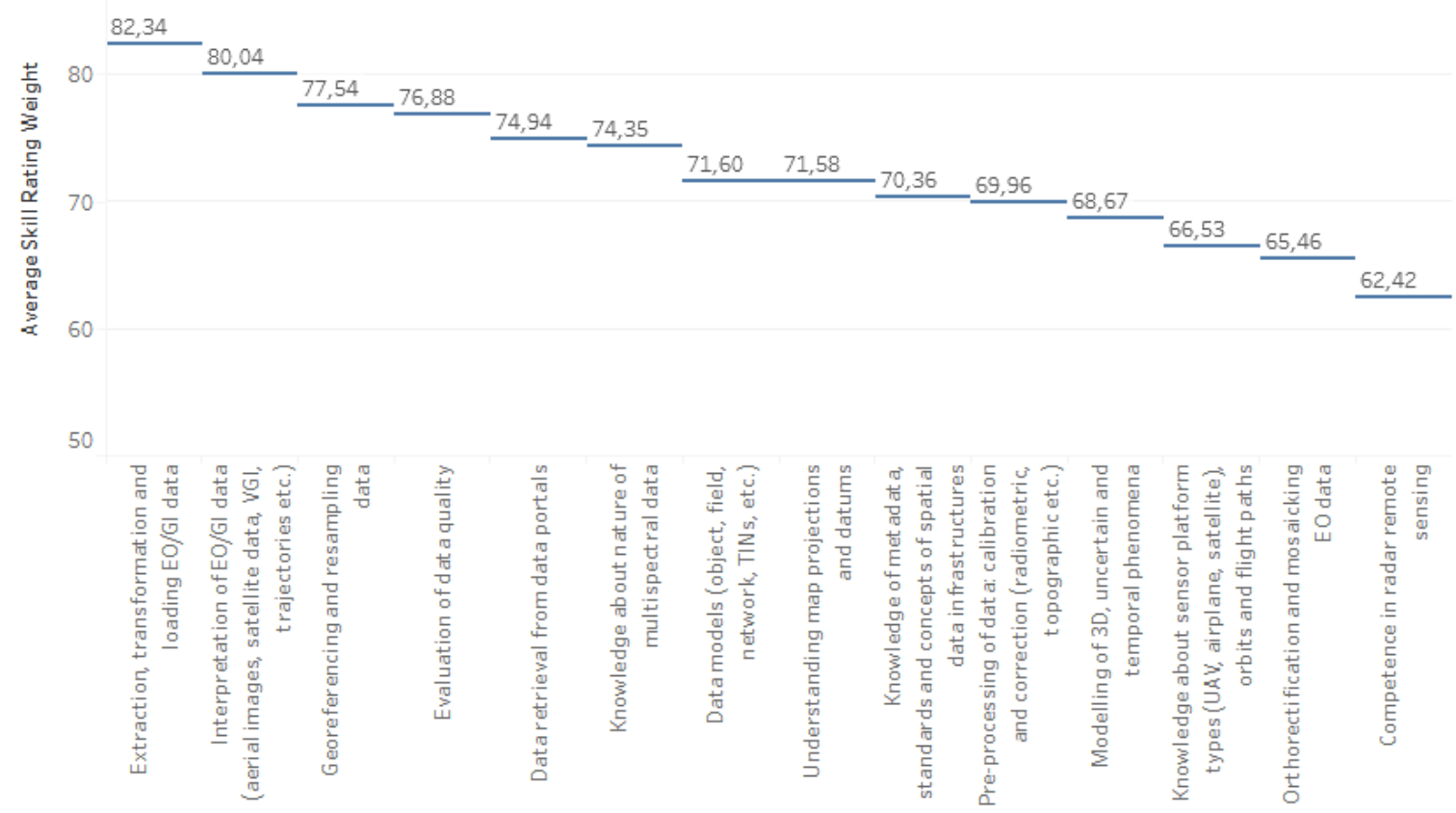

㫱+ + a b le a u

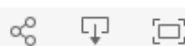

Obr. 3 Hodnocení požadované úrovně dovedností pro oblast Space/Geospatial Data Skills (Albrecht, 2018b)

Zajímavé je, že jako nejvíce náročné se jim ukázala dovednost Extrakce, transformace a stahování EO/GI dat (Extraction, transformation and loading EO/GI data). Následně se hodnotily i úrovně dovedností $v$ jednotlivých skupinách. Pak pro každý dílćí, např. vizualizace a kartografie (obr.4).

Průzkum ukázal, že respondenti mají tendenci charakterizovat potenciální zaměstnance podle jejich vlastního vzdělání a kariérní dráhy. Většina organizací také má poměrně různorodou představu, jak jsou konkrétní dovednosti spojeny se profilem nějakého povolání. $V$ průzkumu dostávaly nejvyšší prioritu dovednosti spojené s daty. Na základě průzkumu byly navrženy 3 hlavní profily povolání: EO/GI vývojář (EO/GI developer), EO/GI datový analytik (EO/GI data analyst) a EO/GI projektový manažer (EO/GI project manager).

Jako jedno z významých zjištění je, že dochází k posunu požadavků od klasického použití DPZ směrem k programování, cloudovým výpočtům, harvestování a lepšímu porozumění výpočetním systémům.

Vzniká i představa různých úrovní vzdělání pro oblast Copernicus, zahrnující techniky (Copernicus practitioner), datové agenty (Copernicus data broker) a projektové manažery (Copernicus project manager). $\mathrm{K}$ tomu poslednímu směřuje př́prava společného Erasmus+ magisterského studia "Copernicus Master in Digital Earth“, vedeného Univerzitou Salzburg. 
90

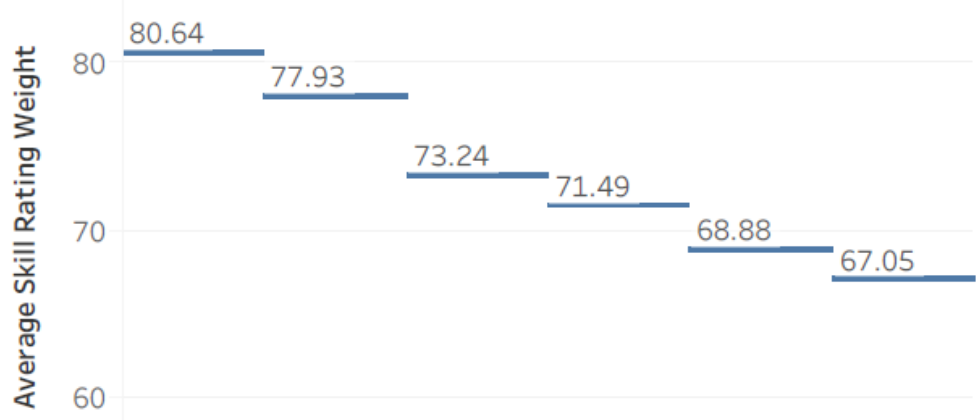

50

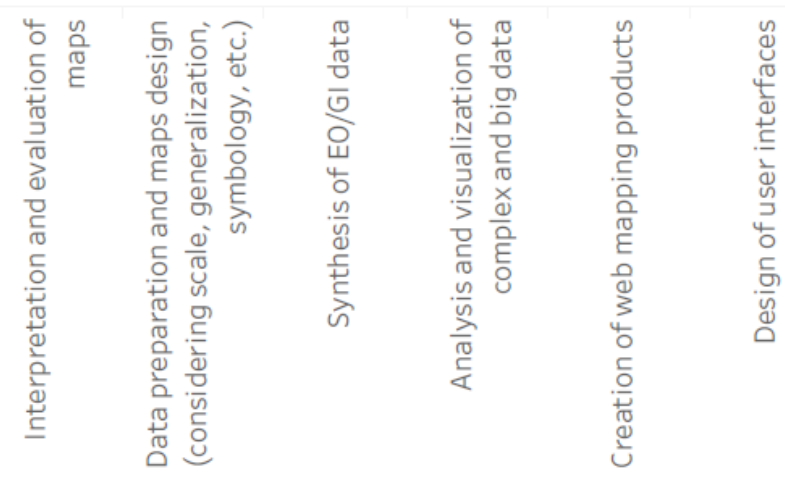

Obr. 4 Průměrné požadované váhy jednotlivých dovedností pro skupinu vizualizace a kartografie (Hofer et al., 2019)

Analýza nabídek pracovních pozic na síti Linkedln (Gruijthuijsen et al., 2019), kde se zjištovaly název pracovní pozice, sektor, požadavky, požadované dovednosti. Podrobně bylo analyzováno 118 nabídek. Nejčastěji požadované dovednosti byly ve skupině Programování a vývoj (27\%), Analytické metody (26\%) a Předzpracování či modelování prostorových dat (22\%) (obr. 5).

\section{Distribution of skillsets}
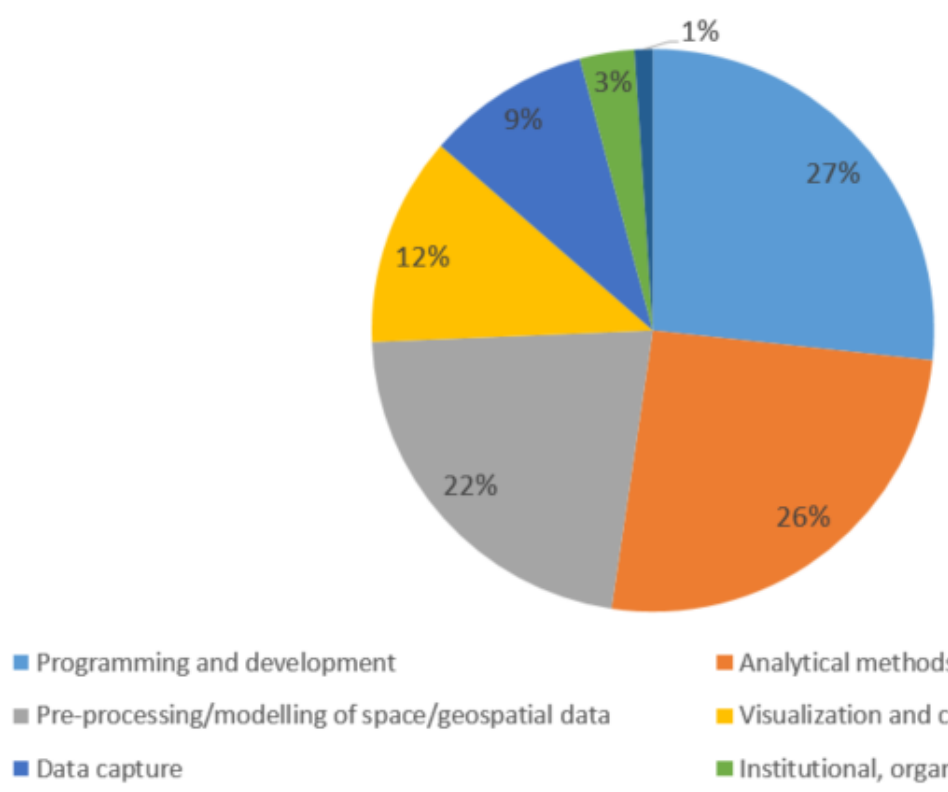

Obr. 5 Distribuce požadavků na skupiny dovedností podle analýzy nabídek v Linkedln (Gruijthuijsen et al., 2019) 
Samozřejmě každá profese má jinou skladbu požadavků (obr. 6).

GIS Specialist
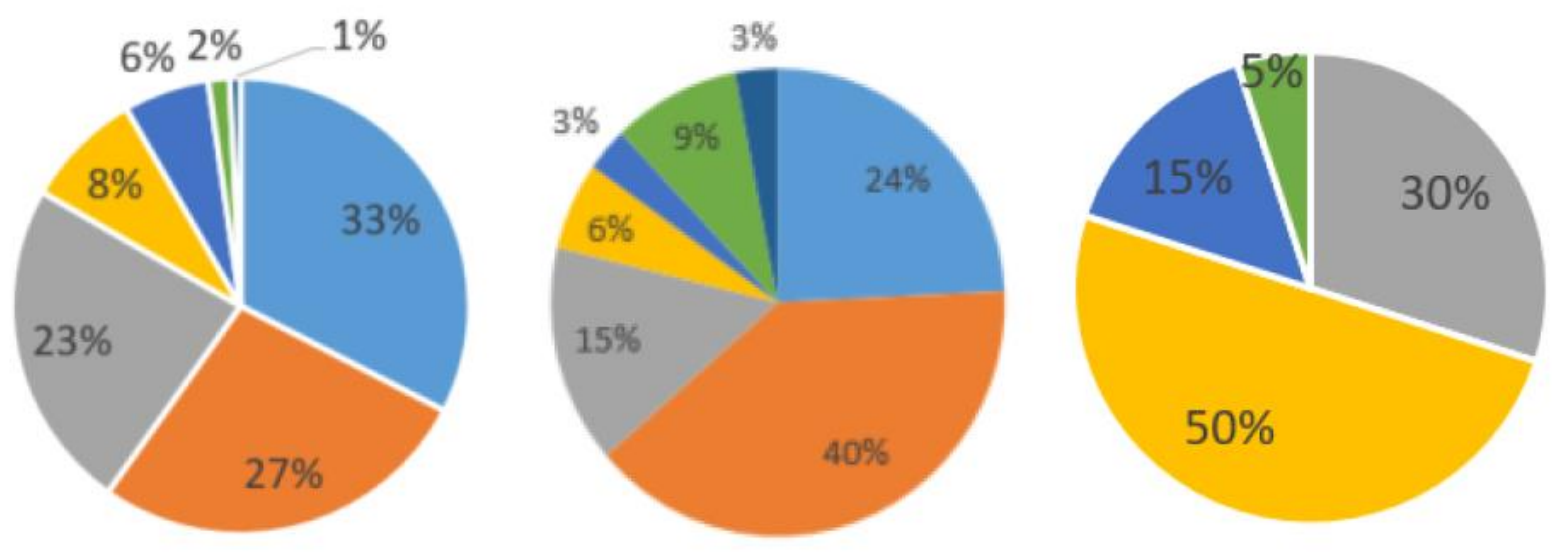

\footnotetext{
- Programming and development

- Analytical methods

- Pre-processing/modelling of space/geospatial data = Visualization and cartography

- Data capture

- Institutional, organizational and society

- Computing resources and platforms
}

Obr. 6 Distribuce požadovaných dovedností pro 3 profese - GIS specialista, Technik DPZ a Kartograf (Gruijthuijsen et al., 2019)

V nově prípravovaném BoK se pokračuje v ontologickém prístupu z projektu GI-N2K (Ahearn et al., 2013). Nové náměty po revizi poslední verze BoK se zaměřením na DPZ a Copernicus jsou prohloubení základů DPZ, lepším rozdělení na pasivní a aktivní platformy, doplnění částí k radaru, lidaru, termálnímu snímání, poskytovatelé dat DPZ, specifické algoritmy pro vybrané snímače (např. terénní korekce, interferogram, rozbalení fáze, koregistrace), nové algoritmy zpracování dat jako strojové učení, cloudové služby, hodnocení kvality, diseminace produktů a znalostí (Olijslagers et al., 2019).

Další zajímavou analýzou je rozbor obsahu 12 jiných BoK (zejména prvních 8 BoK, o nichž je dostupných více informací) (Martirano et al., 2019):

- The European Foundational ICT Body of Knowledge

- The EITBOK - Enterprise Information Technology Body of Knowledge

- The Business Analysis BOK (BABOK)

- Business Architecture Body of Knowledge (BizBoK)

- Data Management BOK (DAMA DMBOK)

- Enterprise Architecture BOK (EABOK)

- Systems Engineering BOK (SEBOK)

- GEOINT Essential Body of Knowledge (GEOINT EBK).

- Product Management and Marketing Body of Knowledge (ProdBOK)

- Project Management BOK (PMBOK)

- Software Extension to the PMBOK (SWX)

- Software Engineering BOK (SWEBOK)

Porovnávaly se rovněž BoK i mezi sebou (obr.7) 


\begin{tabular}{|c|c|c|c|c|c|c|c|c|}
\hline Knowledge Areas & ICT BOK & EIT BOK & BABOK & BizBok & DAMA DMBOK & EABOK & SEBOK & GEOINT EBK \\
\hline $\begin{array}{c}\text { Data Modeling \& } \\
\text { Design }\end{array}$ & & & & & YES & & & \\
\hline $\begin{array}{l}\text { Data Storage \& } \\
\text { Operations }\end{array}$ & & & & & YES & & & \\
\hline Data Security & YES & YES & & & YES & YES & & \\
\hline $\begin{array}{l}\text { Data Integration \& } \\
\text { Interoperability }\end{array}$ & YES & YES & & & YES & & & \\
\hline $\begin{array}{c}\text { Document \& Content } \\
\text { Management }\end{array}$ & & & & & YES & & & \\
\hline $\begin{array}{c}\text { Reference \& Master } \\
\text { Data }\end{array}$ & & & & & YES & & & \\
\hline $\begin{array}{l}\text { Data Wharehousing \& } \\
\text { Business Intelligence }\end{array}$ & & & & & YES & & & \\
\hline Metadata & & & & & YES & & & \\
\hline Data Quality & YES & YES & & & YES & & & \\
\hline
\end{tabular}

Obr.7 Shoda ICT BoK s dalšími BoK (Martirano et al., 2019)

Z porovnání pak vzešel návrh doplnit do EO/GI BoK také témata Bezpečnost dat a Kvalita dat. Projekt ještě není ukončen, ale již přináší zajímavé studie a analýzy, které lze využít při plánování vlastních vzdělávacích programů.

\section{ZÁVĚR}

Na uvedených př́kladech je možné doložit potřebu sledovat vývoj mezinárodních a zejména evropských kmenů znalostí $v$ oblasti prostorových informací. Vycházejí $z$ analýzy požadavků, analýzy pracovních nabídek, prípadových studií, analýz trendů a jsou proto významné i z hlediska hodnocení vývoje oboru, zejména pro monitoring a plánování potřeb lidských zdrojů.

Materiály je možno využít při přípravě specifikace povolání a požadovaných dovedností a kompetencí. Jinou oblastí jejich využití je tvorba vzdělávacích kurzů a zejména vysokoškolských programů.

CAGI v rámci činnosti OS Vzdělávání připravila nabídku kurzů akreditovaných pro úředníky veřejné správy. $\checkmark$ první etapě jde o 3 kurzy, 2 déledobé a jeden krátký (UAV):

- Geografické informační systémy pro e-government I

- Geografické informační systémy v územním plánování

- Bezpilotní letecké prostředky v ochraně životního prostředí

Pokud to koronovirová epidemie umožní, mohou se spustit na podzim 2020.

\section{LITERATURA}

1. Ahearn, S., Icke, I., Data, R., DeMers, M.N., Plewe, B. and Skupin, A. (2013). Re-engineering the GIS\&T Body of Knowledge. In International Journal of Geographical Information Science (IJGIS), Volume 27, 2013, Issue 11, CyberGIS -Blueprint for Integrated and Scalable Geospatial Software, p. 2227-2245.

2. Albrecht, F. (2018a): Most needed Position Matrix Role/function and field of expertise. Dostupné https://public.tableau.com/views/EO4GEO_Demand_Survey_Part3_MNP_FA/MostNeeded PositionMatrixrolefunctionandfieldofexpertise?

3. Albrecht, F. (2018b): Space/Geospatial Data. Dostupné na https://public.tableau.com/views/EO4GEO_Demand_survey_Part5_SkillSets_Details/Dash boardSpace?:embed=y\&:display_count=yes

4. Čada, V., Kympergrová, K., Fiala, R., Hündl, V., Hampl, S. (2016): Metodika vyhodnocování lidských zdrojů v oblasti prostorových informací. Certifikovaná metodika. Dostupné na: https://www.mvcr.cz/soubor/metodika-lidske-zdroje-pdf.aspx 
5. DiBiase D., DeMers M., Johnson A., Kemp K., Luck A.T., Plewe B., Wentz E. (Eds.) (2006): Geographic Information Science and Technology Body of Knowledge. University Consortium for Geographic Information Science. Publikováno Association of American Geographers, 1.vydání, 2006.

6. Gruijthuijsen, W., De Brito Pontes, M., Vancauwenberghe, G.(2019): D 1.5 -Skills shortages, gaps and mismatches between supply and (future) demand. KU LEUVEN, 11/2019. Dostupné na

http://www.eo4geo.eu/download/eo4geo_d1-5-skills-shortages-gaps-and-mismatchesbetween-supply-and-future-demand_v2-2/?wpdmdl=4773\&masterkey=5e454ec9238e 2

7. GTCM (2014): Geospatial Technology Competency Model. https://www.scribd.com/document/241547194/Geospatial-Industry

8. Hofer, B., d'Oleire Oltmanns, S., Ferber, N., Albrecht, F., Lang, S. (2019). D 1.3 - Demand for space/geospatial education and training and priority occupational profiles. Dostupné na http://www.eo4geo.eu/download/eo4geo_d1-3_demand_for_spacegeospatial_education_and_training_and_priority_occupational_profiles_v2$1 /$ ?wpdmdl=3840\&masterkey $=5$ cfe849bd 1 fee

9. Horák J., Rapant P., Inspektor T., Čada V., Jedlička K. (2016): Analýza rozdílů mezi učebními osnovami programů v oblasti prostorových informací v ČR a zahraničí. Ostrava, 2016. 118 stran.

10. Horák J., Rapant P., Jedlička K., Čada V., Inspektor T. (2017a): Národní kmen znalostí GIS\&T a obsah vzdělávání v ČR. In sborník „GIS Ostrava 2017 - Geoinformatika v pohybu“, Ostrava,

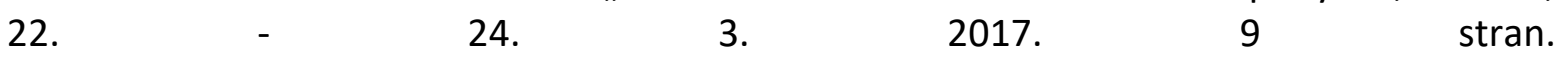
http://gisak.vsb.cz/GIS_Ostrava/GIS_Ova_2017/sbornik/papers/gis20175841e8bba141e.pd $f$

11. Horák J., Rapant P., Jedlička K., Čada V., Inspektor T. (2017b): Analýza obsahu vysokoškolského studia GIS\&T v ČR a zahraničí. In sborník „GIS ve veřejné správě“. Praha. 4. - 5. 5. 2017. Dostupné na https://www.cagi.cz/upload/documents/givs2017/13_horakanalyza_obsahu_vs_studia_gis-t.pdf.

12. Horák, J. (2019a): Aktivity CAGI v oblasti vzdělávání. In Sborník „GIS Ostrava 2019 - Smart City, Smart Region“, 20. - $\quad 22 . \quad$ března 2019. http://gisak.vsb.cz/GIS_Ostrava/GIS_Ova_2019/sbornik/papers/gis20195bf7ca48675cf.pdf

13. Horák J. (2019b): Potřeby a př́ležitosti vzdělávání v geoinformatice. In Sborník GIS ve veřejné správě 2019. CAGI, Praha, 20-21-.5.2019. 16 s. Dostupné na http://www.cagi.cz/upload/documents/konference/givs2019/givs-2019-10-horakpaper.pdf.

14. Jedlička K., Horák J., Kocich D., Inspektor T., Čada V. (2017): Projekce technologického vývoje v oblasti geoinformatiky. In sborník "GIS Ostrava 2017 - Geoinformatika v pohybu“, Ostrava, 22. - 24. 3. 2017. 13 stran. Dostupné na http://gisak.vsb.cz/GIS_Ostrava/GIS_Ova_2017/sbornik/papers/gis201758452da337442.pd f

15. Martirano, G., Bilotti, L., Vercillo, A. (2019): D 2.4-Linking the BoK for GI and EO to other BoKs. Dostupné na: http://www.eo4geo.eu/download/eo4geo_d2-4-linking-the-bok-for-giand-eo-to-other-boks_v2-1/?wpdmdl=4543\&masterkey=5dc176f43b645

16. Olijslagers, M., Vancauwenberghe, G., Vandenbroucke, D., Gruijthuijsen, W. Casteleyn, S., Aguilar, E., Lemmens , R., Stelmaszczuk-Górska, M. (2019): D 2.2-Revised ontology-based approach. Dostupné na: http://www.eo4geo.eu/download/eo4geo_d-2-2-revisedontology-based-approach_v2-0/?wpdmdl=3491\&masterkey=5c5b01d87d8bd 
17. Oliver, G.R. (2012). Foundations of the Assumed Business Operations and Strategy Body of Knowledge (BOSBOK): An Outline of Shareable Knowledge, p.3. 